\title{
Work Factors and Commitment of Public Health Care Providers, in Oromiya Region, Ethiopia/2010: The Case of Equity and Extrinsic Factors
}

\author{
Girma Tenkolu Bune*, Solomon Hailemariam Tesfaye, Henok Tadesse Ayele, \\ Tadesse Alemu Zerfu \\ Dilla University, Dilla, Ethiopia \\ Email: "girmatenkolu1973@gmail.com, solomon0917242124@gmail.com, hennypho@yahoo.com, \\ tadal2005@yahoo.com
}

Received 7 April 2014; revised 17 May 2014; accepted 27 June 2014

Copyright (C) 2014 by authors and OALib.

This work is licensed under the Creative Commons Attribution International License (CC BY). http://creativecommons.org/licenses/by/4.0/

(c) $\underset{\mathrm{EY}}{\mathrm{B}}$ Open Access

\begin{abstract}
Statistical report of the Ethiopian Federal Ministry of Health for the years 2006/7 shows that the number of health professionals in the country is insignificant compared to the demand of the population. The objective of this study is assessing the factors which reduce the commitment of the professional health workers and force them to flee away to other places. For that, a cross-sectional design with multi-stage stratified sampling technique on a total of 660 health workers was employed. Following, the reliability of our data collection tools was assessed and then, principal component analysis with varimax rotation to identify components of the composite extrinsic factors with higher variance was also done. After that, factor scores, correlations, and stepwise multiple linear regressions were calculated. A total of 573 participants with a response rate of $86.03 \%$ were included in the study. A two-factor solutions from the 10 items with Eigen values $=6.8$ and 1.2 was extracted for extrinsic factors, which were called as extrinsic factor_1 \&_2, and one factor of affective commitment_1 from 6 was also extracted. Lastly, extrinsic factors of work_1 \& _2 (B = $0.202,95 \%$ CI $0.152,0.253, p<0.0001$ and $B=0.231,95 \%$ CI $0.169,0.292, p<0.0001$ ) respectively are considered as predictors of workers commitment. This implies that, the higher workers dissatisfaction with extrinsic factors of work, the lower their affective commitments will be. Therefore, policy makers in the ministry of health should revise their policy to bring some improvement on the extrinsic factors of work such as, salary, fringe benefits, and the incentive system of health care organizations by assessing the conditions of those factors in each health care organization.
\end{abstract}

\section{Keywords}

Work Factors, Public Health Care

${ }^{*}$ Corresponding author.

How to cite this paper: Bune, G.T., Tesfaye, S.H., Ayele, H.T. and Zerfu, T.A. (2014) Work Factors and Commitment of Public Health Care Providers, in Oromiya Region, Ethiopia/2010: The Case of Equity and Extrinsic Factors. Open Access Library Journal, 1: e580. http://dx.doi.org/10.4236/oalib.1100580 


\section{Background}

Economic, social, and political development can only be achieved by building and sustaining effective and productive organizations. This demands human resource management skills. Good human resource management results in attracting, retaining, and satisfying committed employees. Employees join and continue for an organization, as long as they are satisfied by the working conditions [1].

In order to satisfy the ever growing demand for professional health workers throughout the world, we need to add about four million more health workers to the system. The demand is most acute in Africa. This continent bears $24 \%$ of the world's burden of disease, and yet has only $3 \%$ of the global health work force. Of the total of 57 countries falling below the thresh hold density of 2.5 health workers per 1000 people, 36 are in Africa [2]. Therefore, it is widely acknowledged that the number of health workers in Africa is almost negligible compared to the demand and this will surely hinder the continent from achieving the MDGs [3].

The situation in Ethiopia is similar to that of the rest of the continent. Both the population of the country and the rate of attrition and migration of the health workers are growing rapidly. This demands a drastic action both to train more health workers and to retain the existing few. This in turn requires finding ways of increasing motivation, adding satisfaction, and raising commitment levels of the workers. Despite its importance, there is a dearth of studies on organizational commitment in the Ethiopia's health care organization. Moreover, little is known about the relationship between workers factors, job satisfaction, and organizational commitment in the country in general and in the study area in particular [4].

Therefore, we hope that the findings of this study will fill the existing knowledge gap regarding the relationship between satisfaction of the health workers and their output and retain. This will create awareness on the part of the health management in those health institutions about the most determinant variables that can influence the commitment level of the health workers. Furthermore, the study will add to the existing literatures and may serve as additional source for reference and it will also serve as a spring board for other researchers who want to conduct detailed research on the issue.

\subsection{The Effect of Work Factors on Organizational Commitment}

According to Kate and Masako, individual and organizational factors may affect the level of effective commitment [5]. Individual factors include factors such as personality, values orientation, education or age. Hence, Figure 1 is a theoretical framework which was first adopted from relevant literature done before to explain the variables of affective commitment as well as use of Herzberg's two-factor theory and Equity theory to explain the variables of extrinsic factors and equity theory respectively and show the effect of those factors on health workers' affective commitment. Hertzberg found that, when people are satisfied with their jobs, they are concerned about the environment in which they work. Upon satisfaction of these hygiene or maintenance factors, Hertzberg contends, that workers can then be motivated by the content of work, such as opportunities for achievement, etc. Put somewhat differently, if hygiene factors are not fairly satisfied, people will tend not to be interested in the challenges of a more responsible job [6]. Moreover, the relationship of satisfaction with pay to organizational commitment is quite straightforward. To the extent the job allows for adequate financial compensation, a linear and positive relationship between satisfaction with pay and organizational commitment would be observed [7].

\subsection{Equity Theory}

Inequity has both structural and specific components. Structural inequity refers to a belief by workers that a general discrepancy exists between the amount of effort they commit to their work and the rewards offered by the organization. On the other hand, specific inequity refers to situations where employers reward to specific workers on the basis of criteria unrelated to the work. And also the specific workers on the basis of criteria unrelated to employee performance and productivity. Some of the particularistic criteria include blood relationship, friendship or gossip [8]. 


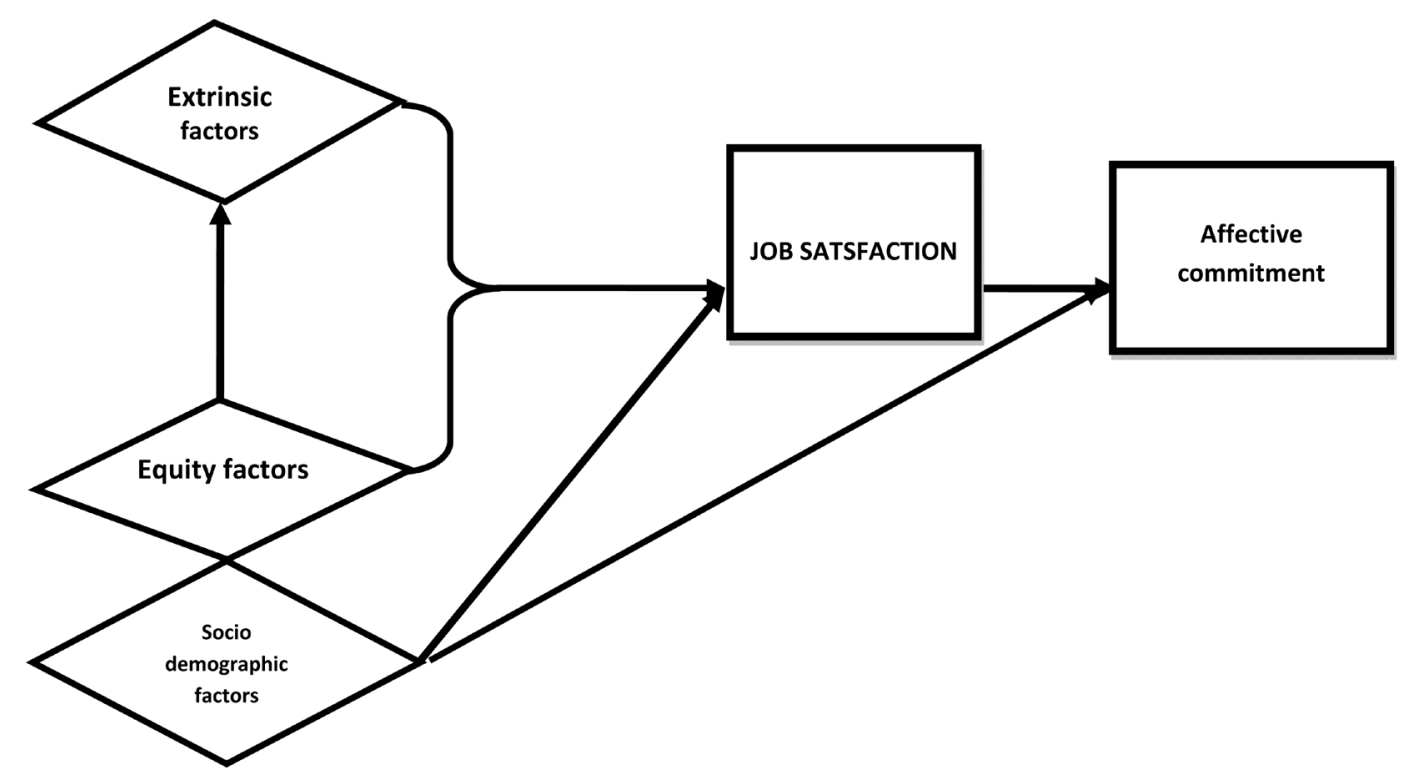

Figure 1. Conceptual framework of the study among governement health workers in Eastern Showa and Adama special zones from March $1^{\text {st }}$ to March $30^{\text {th }}$.

\section{Methods}

\subsection{Study Area and Period}

This study was conducted in Eastern Showa and Adama special zones. Eastern Showa zone is one of the zones of Oromiya region with 13 districts. Within these districts there are a total of 55 health centers. From these health centers, only 26 are providing service to the community. The rest 33 of the health centers are opened recently and have not yet started offering service. Together, there are 301 health posts that are located in the rural part of the zones. Within the 13 districts, there exist 1203 permanent health workers of various professions. This includes 44 health officers, 323 nurses, 33 pharmacy technicians, 40 laboratory technicians, 660 health extension workers and 58 other type of health workers. Adama special zone is also one of the zones in the region where the study was conducted. In this zone, there is only one public hospital called "Adama Teaching and Referral Hospital" and there are also four health centers of which only two are functional. In this zone, there exist 159 health workers with different professions. These are: 4 environmental technicians, 2 x-ray technician, 12 medical doctors, 11 health officers, 8 pharmacist/druggists, 20 laboratory technicians and 102 different nurses. The study was conducted from March 1st to 30th 2010.

\subsection{Study Design}

A facility based cross sectional study design was employed.

\subsection{Source Population}

All health workers working in the public health facilities of the study zones were considered as the source populations.

\subsection{Study Population}

Sampled health workers in the government health institutions who were fulfilling the inclusion criteria were included in the study.

\subsection{Inclusion and Exclusion Criteria}

Health workers who had been serving for 6 month or more in the government health institutions and who were permanent employees of the organizations were included in the study. A seriously ill and mentally disabled 
health worker in the government health institutions were excluded from the study.

\subsection{Sampling Technique}

A multi-stage stratified random sampling technique was employed.

\subsection{Sampling Procedure}

First the health institutions which were found in both zones were listed with name and stratified with the criteria of level of service delivery. There were only 28 primary health care units (PHCU) and 1 hospital which provide service to the community. By considering resource available at hand, sixty percent of PHCU were selected by using simple random sampling technique. Therefore, in addition to Adama referral hospital, the study included 17 PHCUs that are named as Awash Melkassa, Cheffe Donsa, Adulala, Wonji Kuruftu, Shewoa Alemtena, Walnchity, Doni, Algea, Mojo, Maqi, Qoqa, Bote, Methara, Batu, Adama, Geda, Bulbula, health centers together with their 5 satellite health posts. All health workers who were employed in the above health institutions became the study subjects.

\subsection{Sample Size Determination}

The sample was calculated using single population proportion estimation formula with $5 \%$ level of significance assuming estimated proportion 50\% for affective commitment, and margin of error $5 \%$. Though the sample size required for the study was 384, the total number of health professionals found in the two zones was 1381 which is less than 10,000. Therefore, by using population correction formula, the total sample size required became 300. However, due to design effect of the study, the calculated final sample size was multiplied by two and adding anticipated non-response $10 \%$, the final required sample size was $300 * 2=600+60=660$.

\subsection{Data Collection Methods and Procedure}

A total of 8 data collectors and 4 supervisors were involved after two days of intensive training. The data collectors were grade 12 complete who can speak both "Oromiffa \& Amharic" and had previously been involved in similar activities. A self-administered questionnaire was distributed to health workers who were included on the final sample at their respective post of service delivery. The instrument was adopted from literature done on previous study [1], adapted in to local context and then translated in to "Amharic" and back translated in to original version with the help of two language experts. It consists of 4 parts. The first is socio demographic part that consists of 11 questions which were planned to collect personal information related to individual identity like age, sex, marital status, professional class, residence (urban/rural), income and work experience. The second is extrinsic factors of work that measure the degree of worker dissatisfaction/no dissatisfaction level with 10 items. The third is perception of equity scale which measures employee's perceptions on 5 items. These were prepared according to Tansik et al. (1980) [8]. The items were meant to assess workers perception regarding their health care manager whether or not the managers are treating workers with in an equitable/inequitable way. These variables were measured using Meyer and Allen's affective Organizational Commitment Scale [9]. This scale contains six-item components to examine the degree of workers emotional attachment with their organizations, their intension to stay with the health care organization, willingness to exert high level of effort on behalf of the organization, and degree of belief in and acceptance of values and goals of the organization. All of the above questions were prepared on a Likert scale.

\subsection{Reliability}

Reliability was assessed before any analysis was held by calculating Cronbach's coefficient alpha for all likert scale questions. Cronbach's alpha for the extrinsic factors of work and affective commitment scale were computed and well exceeded 0.7 (Table 4, Annex) according to the criterion suggested by Nunnally, J.C. However, all items of equity factors of work were excluded from further analysis due to lack of reliability [10].

\subsection{Variables}

\subsubsection{Dependent}

Affective commitment. 


\subsubsection{Intermediate Variable}

Job satisfaction.

\subsubsection{Independent}

Socio demographic factors, extrinsic factors of work that includes: salaries, promotion, job security, fringe benefits, opportunity for training, company policies, quality of technical supervision.

\subsubsection{Equity Factors of Work}

Structural inequity, specific inequity.

\subsection{Operational Definition}

\subsubsection{Affective Commitment}

Is defined as the health workers emotional attachment to their health care organization that, workers strongly identifies with the goals of the health care organization and desires to remain a part of the organization. To decide whether the workers are committed or not, mean was calculated and those mean scoreless or equal to 3 , was categorized as low affective commitment, and those score above 3.01 as grouped high affective commitment.

\subsubsection{Job Satisfaction}

Is defend by the degree that how well the health care organization meet the work factors. To decide whether the workers are satisfied or not, the mean score of each of the work factors were summed up and divide by the number of factors used. Finally, those mean scores less or equal to 3, were categorized as low satisfactions and those score above 3.01 as grouped as highly satisfied.

\subsubsection{Work Factors}

Are motivational factors which affect ones satisfaction level with his/her job. These include the extrinsic and equity factors.

\subsubsection{Extrinsic Factors of Work}

Extrinsic factors of health work are factors as elements associated with the health work environment, such as: company policy and administration, supervision, relationship with supervision, work conditions, salaries, relationship with peers, personal life, relationship with staff, status, job security. To decide whether or not workers are less dissatisfied/highly dissatisfied with extrinsic factors of work, mean for each items were calculated, and for the result less or equal to 3 , it was decided as not dissatisfied with extrinsic factors of work.

\subsubsection{Equity Factors of Work}

Will be defined in terms of defining in equity in two ways:

1) Structural inequity: refers to a belief by health workers that a general discrepancy exists between the amount of effort they commit to their work and the rewards offered by the health care organization. Decision was made by calculating mean and for the result less or equal to 3 it can be decided as workers dissatisfied with structural inequity.

2) Specific inequity: refers to situations where health care organizations managers reward specific workers on the basis of criteria unrelated to workers' performance and productivity with some of the particularistic criteria include blood relationship, friendship or gossip. Decision was made by calculating mean, results less or equal to 3 show workers' dissatisfaction with specific inequity.

\subsection{Data Quality Management}

Quality of data was maintained through careful design, translation, and retranslation, and pretesting of the instrument on $5 \%$ from the total sample size required on health workers found in health facilities other than the selected one. Moreover, it was also assured through provision of proper training for data collectors and supervisors, close supervision of data collectors and check up of the completeness of the questionnaires.

\subsection{Data Analysis}

All data were coded, entered, and analyzed using the statistical package for the Social Sciences (SPSS) version 
16. The missing values were checked prior to further statistical analysis for its completeness and rejection was made for those questionnaire $>20 \%$ missed items. Appropriate statistical procedures were used for exploring the data. Mean score as a measure of central tendency was used to show where the majority of responses concentrate after the reliability of all Likert scale questions being checked. Subsequently, chi-square test, Principal Component Analyses (PCAs) with Varimax rotation were used to determine the number of factors underlying the items that measure extrinsic factors of work and affective commitment to calculate factor. Finally, correlation and a stepwise multiple linear regressions was made for those significant variables to indentify predictors of health workers affective commitment.

\subsection{Ethical Consideration}

The proposal was submitted to the ethical committee of Jimma University for ethical review and clearance. After permission was obtained, support letters written by the University was submitted to all concerned bodies in the study area. Prior to the initiation of the data collection, written informed consent was obtained from health service organizations and verbal consent from the study subjects. Finally, the study participants were assured about the confidentiality of the information they provided and to maintain confidentiality, the names of the subjects were not registered on the questionnaire.

\subsection{Dissemination Plan}

After everything else, the finding was presented to Jimma University, College of Public Health and Medical Science (JUCPHMS). Subsequently, copy of the whole research were submitted to JUCPHMS and disseminated to all concerned stakeholders like: to the Oromia regional health bureau and to East Showa and Adama special zonal health office. At last, attempts will be made to present it on scientific conferences and publish it on scientific journals.

\section{Result}

\subsection{Socio-Demographic Characteristics of the Respondents}

A total of 573 respondents participated in the study giving a response rate of $86.03 \%$. Of these participants, 417 $(72.8 \%)$ were female with mean age of $(28+6.76)$ with a range of $(19-54)$ year. Majority of these respondents, 179 (31.2\%), were from health posts, and 347 (60.6\%) were married. There was different type of health professionals category participated in the study, nurses accounting to the largest proportion, 240 (41.9\%). Additionally, these participants do have a diverse level of educational background; certificate, diploma, degree, and above degree which accounts 188 (32.8\%), 245 (42.8\%), 125 (21.8\%) and 15 (2.6\%), respectively. The average service year of the respondents was 5 (s.dev.5.8). Two hundred five (35.8\%) participants have a monthly income of less than or equal to 667 birr and 37 (6.5\%) participants had monthly income that ranges between 1637 - 2240 birr as shown in the (Table 1 ).

\subsection{Extrinsic Factors of Work}

The overall dissatisfaction level of the workers were assessed and 303 (52.9\%) workers are less dissatisfied (mean score $=3.1$ and SD = 1.2) (Table 2). They did, however, express greatest dissatisfaction in their salary (mean score $=2.5$ and SD $=1.67)$, their fringe benefit (mean score $=2.7$ and SD $=1.56$ ), promotion and salary increment (mean score $=2.7$ and SD $=1.50$ ), the incentive systems (mean score $=2.8$ and SD $=1.43$ ) and opportunity for outside training (mean score $=2.9$ and SD $=1.44)$ (Table 3$)$.

\subsection{Socio-Demographic Characteristics and Overall Job Satisfaction}

Cross tabulation was made and a significant associations was observed in between overall job satisfaction and socio demographic characteristics like: type of health facility $\left(X^{2}=284.9\right.$, $p$ value $\left.<0.001\right)$, location of health facility $\left(X^{2}=141.7, p\right.$ value $\left.<0.001\right)$, professional category $\left(X^{2}=253.7\right.$, p value $\left.<0.001\right)$, sex $\left(X^{2}=53.1\right.$, $p$ value $<0.001)$, marital status $\left(X^{2}=56.8\right.$, $p$ value $\left.<0.001\right)$, educational level at $\left(X^{2}=216.8, p\right.$ value $\left.<0.001\right)$, income at $\left(X^{2}=227.4, p\right.$ value $\left.<0.001\right)$, age $\left(X^{2}=126.1\right.$, $p$ value $\left.<0.001\right)$ and service year of respondents at $\left(X^{2}=105.4\right.$, p value $\left.<0.001\right)$. Moreover, 210 (99.5) health post and 132 (66.7) of health centers and 275 (85.4) 
Table 1. Socio-demographic characteristics of government health care provider in East Showa and Adama special zone, 2010.

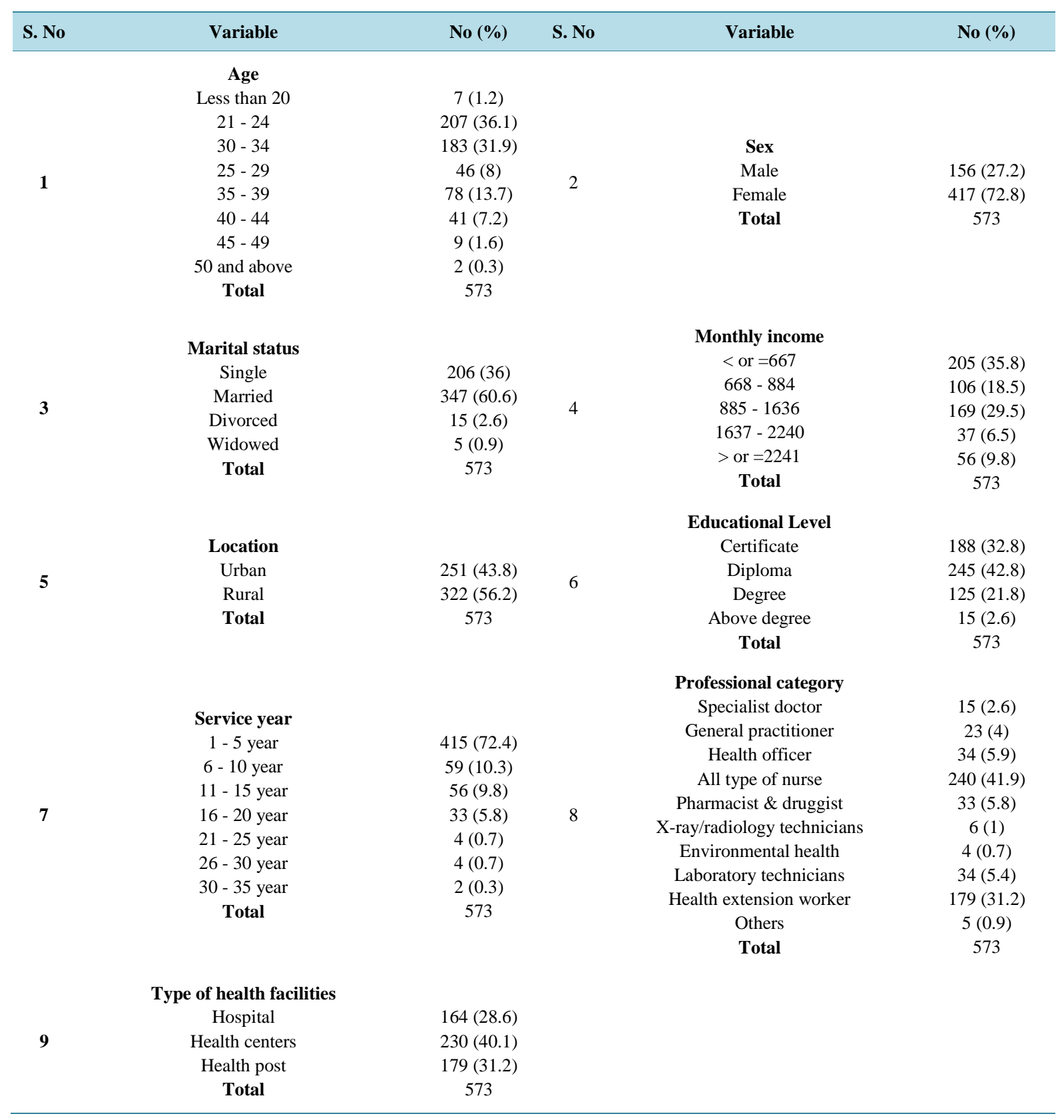

Table 2. Mean score reliability coefficients and level of factors for each scale of extrinsic factors of work and affective commitment, East Showa and Adama special zones, March 1st to 30th, 2010.

\begin{tabular}{|c|c|c|c|c|c|c|c|}
\hline S. No & Factors & $\begin{array}{l}\text { No of } \\
\text { items }\end{array}$ & $\begin{array}{l}\text { Cronbach's } \\
\text { alpha value }\end{array}$ & $\begin{array}{l}\text { Mean } \\
\text { value }\end{array}$ & S.D & Level of factor & No (\%) \\
\hline \multirow[t]{2}{*}{1} & Extrinsic factor of work scale & 10 & 0.947 & 3.11 & 1.2 & $\begin{array}{l}\text { Highly dissatisfied } \\
\text { Less dissatisfied }\end{array}$ & $\begin{array}{l}270(47.1) \\
303(52.9)\end{array}$ \\
\hline & Over all job satisfaction & & & 3.51 & 0.93 & $\begin{array}{l}\text { Highly satisfied } \\
\text { Less satisfied }\end{array}$ & $\begin{array}{c}355(62) \\
196(34.2)\end{array}$ \\
\hline 2 & Affective commitment & 6 & 0.962 & 3.32 & 1.4 & $\begin{array}{l}\text { Highly committed } \\
\text { Less committed }\end{array}$ & $\begin{array}{c}488(85.2) \\
85(14.8)\end{array}$ \\
\hline
\end{tabular}


Table 3. Extrinsic factors of work among government health care providers in the Eastern Showa and Adama special zones in 2010.

\begin{tabular}{|c|c|c|c|c|c|c|c|c|}
\hline \multirow{2}{*}{ S. No } & \multirow{2}{*}{$\begin{array}{c}\text { Extrinsic } \\
\text { factors of work }\end{array}$} & S. Disagre & Disagree & Indifferent & Agree & S. Agree & \multirow{2}{*}{ Mean } & \multirow{2}{*}{ S.D } \\
\hline & & No (\%) & No (\%) & No (\%) & No (\%) & No (\%) & & \\
\hline 1 & $\begin{array}{l}\text { I'm satisfied with } \\
\text { the salary }\end{array}$ & 244 (42.6\%) & $126(22.0 \%)$ & 10 (1.7\%) & $51(8.9 \%)$ & $142(24.8 \%)$ & 2.5 & 1.67 \\
\hline 2 & $\begin{array}{l}\text { I'm satisfied with } \\
\text { the fringe benefits }\end{array}$ & 156 (27.1\%) & 197 (34.4\%) & $16(2.8 \%)$ & 64 (11.2\%) & 144 (24.6\%) & 2.7 & 1.56 \\
\hline 3 & $\begin{array}{l}\text { I'm satisfied with the } \\
\text { promotion and } \\
\text { salary increment }\end{array}$ & 163 (28.4\%) & 180 (31.4\%) & 31 (5.4\%) & 91 (15.9\%) & 108 (18.8\%) & 2.7 & 1.5 \\
\hline 4 & $\begin{array}{l}\text { I'm satisfied with } \\
\text { the job security }\end{array}$ & 94 (16.4\%) & 105 (18.3\%) & 35 (6.1\%) & 199 (34.4\%) & 140 (24.4\%) & 3.3 & 1.44 \\
\hline 5 & $\begin{array}{l}\text { I'm satisfied with the } \\
\text { health management } \\
\text { welfare consideration }\end{array}$ & 94 (16.4\%) & 135 (23.6 \%) & 45 (7.9\%) & 150 (26.2\%) & 149 (26\%) & 3.2 & 1.47 \\
\hline 6 & $\begin{array}{l}\text { I'm satisfied with the } \\
\text { incentive System }\end{array}$ & 123 (21.5\%) & $184(32.1 \%)$ & 27 (4.7\%) & 146 (25.5\%) & 93 (16.2\%) & 2.8 & 1.43 \\
\hline 7 & $\begin{array}{l}\text { I'm satisfied with the } \\
\text { opportunity for } \\
\text { outside training }\end{array}$ & 131 (22.9\%) & 129 (22.5\%) & $26(4.5 \%)$ & 206 (36\%) & 81 (14.1\%) & 2.9 & 1.44 \\
\hline 8 & $\begin{array}{l}\text { I'm satisfied with the } \\
\text { opportunity for } \\
\text { in-house training }\end{array}$ & 68 (11.9\%) & 149 (26.0\%) & 25 (4.4\%) & 178 (31.1\%) & 153 (26.7\%) & 3.4 & 1.41 \\
\hline 9 & $\begin{array}{l}\text { I'm satisfied with the } \\
\text { post employment } \\
\text { security }\end{array}$ & 58 (10.1\%) & 96 (16.8\%) & 58 (10.1\%) & 177 (30.9\%) & $184(32.1 \%)$ & 3.6 & 1.35 \\
\hline 10 & $\begin{array}{l}\text { I'm satisfied with the } \\
\text { relationship with } \\
\text { co-workers }\end{array}$ & 49 (8.6\%) & 44 (7.7\%) & 7 (1.2\%) & $233(40.7 \%)$ & 240 (41.9\%) & 4 & 1.23 \\
\hline
\end{tabular}

workers who reside in the rural part of the area were highly satisfied with their context of job, and 212 (99.1) health extension workers, 309 (74.1) female, 197 (56.8) married, 169 (82) single, 203 (99) and 26 (70.3) of workers who earn monthly income of $<667$ birr and in between 1636 - 2241 birr per month were highly satisfied with their job. Similarly, 18 (94.7) of health workers whose age was less than 20 and 312 (78.4) range between 21 - 30, 322 (65.8) who served the institutions 1 - 5 years were also highly satisfied with their job (Table 4).

\subsection{Affective Commitment}

Four hundred eighty eight (85\%) workers of the two zones were highly committed to their health care organization with (mean score $=3.32$, SD $=1.4$ ) (Table 2). Similarly, they were also scored above the expected middle value for all constructs of affective commitments (Table 5).

\subsection{Socio-Demographic Characteristics and Affective Commitment}

Statistically significant associations were observed in between the mean overall commitment score and the socio-demographic characteristics of health workers; type of health facility $\left(X^{2}=375.7\right.$, $p$ value $\left.<0.001\right)$, location of health facility $\left(X^{2}=256.6\right.$, $p$ value $\left.<0.001\right)$, professional category $\left(X^{2}=261.6\right.$, $p$ value $\left.<0.001\right)$, sex $\left(X^{2}=\right.$ 74.209, $\mathrm{p}$ value $<0.001)$, marital status $\left(X^{2}=44.264\right.$, $\mathrm{p}$ value $\left.<0.001\right)$, educational level at $\left(X^{2}=241.2\right.$, $p$ value $<0.001)$, income at $\left(X^{2}=254.2\right.$, p value $\left.<0.001\right)$, age $\left(X^{2}=182.7\right.$, p value $\left.<0.001\right)$ and service year of respondents at $\left(X^{2}=152.5\right.$, p value $\left.<0.001\right)$. Therefore, 211 (100\%) health post, 131 (66.2\%) health center, 287 (89.1\%) rural $214(100 \%)$ health extension and $4(100 \%)$ other type of health workers were highly committed. Similarly, 296 (71\%) female, 179 (51.6\%) married, 159 (77.2\%) single, 217 (99.1\%) certificate holder, 22 (59.5) who got 1637 - 2240 birr/ month, 63 (59.4\%) who got less than 667 birr/ month, 303 (76.1\%) whose age in be- 
Table 4. Comparison of the overall job satisfaction and affective commitment level using the socio-demographic characteristics of government health care providers in Eastern Showa and Adama special zone, March $1^{\text {st }}$ to March $30^{\text {th }}, 2010$.

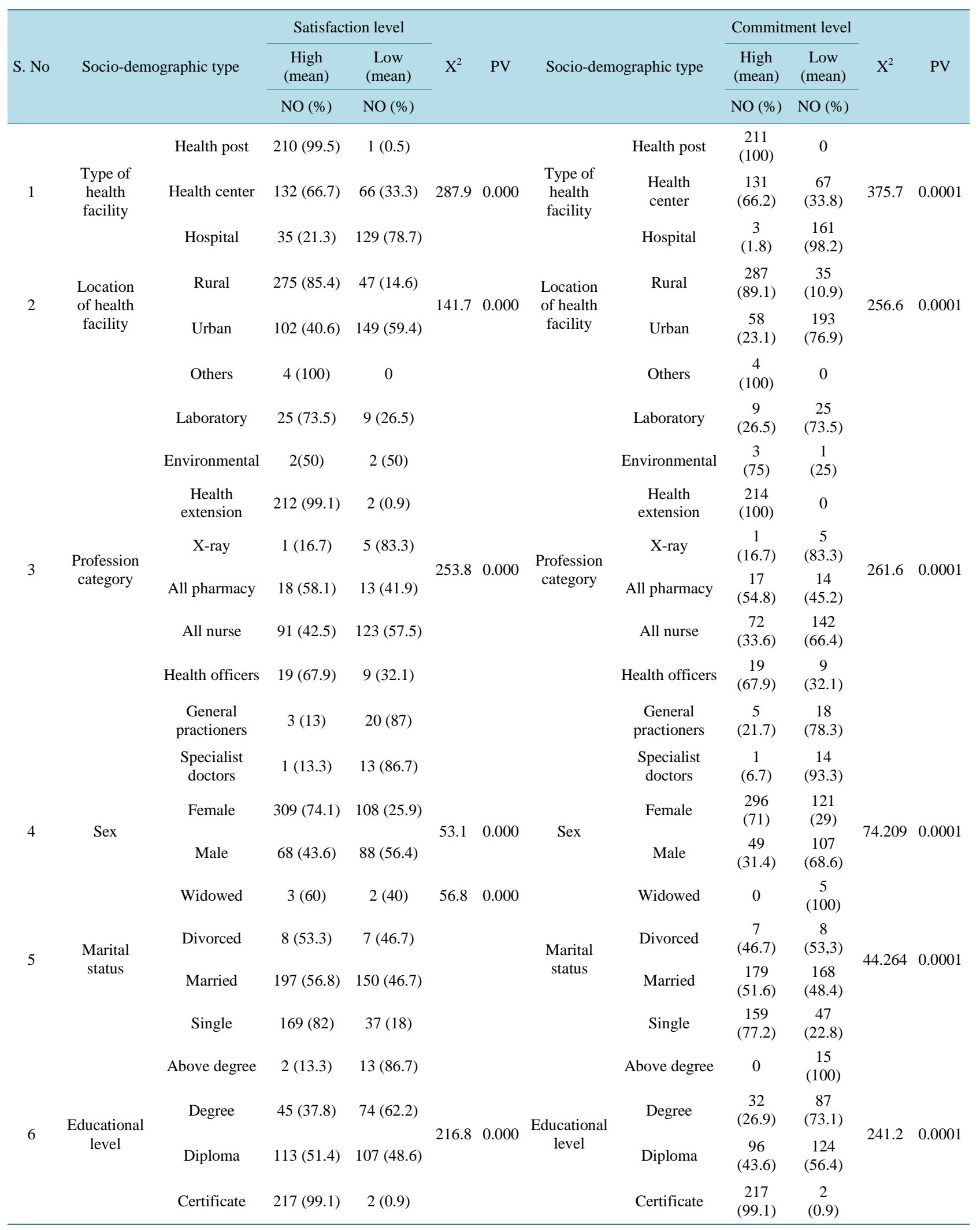




\begin{tabular}{|c|c|c|c|c|c|c|c|c|c|c|c|c|}
\hline \multicolumn{13}{|c|}{ Continued } \\
\hline \multirow{4}{*}{7} & \multirow{4}{*}{$\begin{array}{c}\text { Income } \\
\text { birr/Month }\end{array}$} & $>2241$ & $12(21.4)$ & 44 (78.6) & \multirow{4}{*}{227.4} & \multirow{4}{*}{0.000} & \multirow{4}{*}{ Income } & $>2241$ & $\begin{array}{c}7 \\
(12.5)\end{array}$ & $\begin{array}{c}49 \\
(87.5)\end{array}$ & \multirow{4}{*}{254.2} & \multirow{4}{*}{0.0001} \\
\hline & & $1637-2240$ & $26(70.3)$ & 11 (29.7) & & & & $1637-2240$ & $\begin{array}{c}22 \\
(59.5)\end{array}$ & $\begin{array}{c}15 \\
(40.5)\end{array}$ & & \\
\hline & & $668-884$ & 67 (63.2) & 39 (36.8) & & & & $668-884$ & $\begin{array}{c}49 \\
(29)\end{array}$ & $\begin{array}{l}120 \\
(71)\end{array}$ & & \\
\hline & & $<667$ & 203 (99) & $2(1)$ & & & & $<667$ & $\begin{array}{c}63 \\
(59.4)\end{array}$ & $\begin{array}{c}43 \\
(40.6)\end{array}$ & & \\
\hline \multirow{5}{*}{8} & \multirow{5}{*}{ Age } & $>51$ & $1(50)$ & $1(50)$ & & & & $>51$ & 0 & $\begin{array}{c}2 \\
(100)\end{array}$ & \multirow{5}{*}{182.7} & \multirow{5}{*}{0.0000} \\
\hline & & $41-50$ & $16(40)$ & $24(60)$ & & & & $41-50$ & $\begin{array}{c}7 \\
(17.5)\end{array}$ & $\begin{array}{c}33 \\
(82.5)\end{array}$ & & \\
\hline & & $31-40$ & 30 (26.3) & 84 (73.7) & 126.1 & 0.000 & Age & $31-40$ & $\begin{array}{c}17 \\
(14.9)\end{array}$ & $\begin{array}{c}97 \\
(85.1)\end{array}$ & & \\
\hline & & $21-30$ & $312(78.4)$ & 86 (21.6) & & & & $21-30$ & 30376.1 & $\begin{array}{c}95 \\
(32.9)\end{array}$ & & \\
\hline & & $<20$ & 18 (94.7) & $1(5.3)$ & & & & $<20$ & $\begin{array}{c}18 \\
(94.7)\end{array}$ & $\begin{array}{c}1 \\
(5.3)\end{array}$ & & \\
\hline \multirow{5}{*}{9} & \multirow{5}{*}{$\begin{array}{c}\text { Service } \\
\text { year }\end{array}$} & $>21$ & $6(60)$ & $4(40)$ & \multirow{5}{*}{105.4} & \multirow{5}{*}{0.000} & \multirow{5}{*}{$\begin{array}{c}\text { Service } \\
\text { year }\end{array}$} & $>21$ & $\begin{array}{c}5 \\
(50)\end{array}$ & $\begin{array}{c}5 \\
(50)\end{array}$ & \multirow{5}{*}{152.5} & \multirow{5}{*}{0.000} \\
\hline & & $16-20$ & $9(27.3)$ & $24(72.7)$ & & & & $16-20$ & $\begin{array}{c}3 \\
(9.1)\end{array}$ & $\begin{array}{c}30 \\
(9.9)\end{array}$ & & \\
\hline & & $11-15$ & $12(21.4)$ & 44 (78.6) & & & & $11-15$ & $\begin{array}{c}3 \\
(5.4)\end{array}$ & $\begin{array}{c}53 \\
(94.6)\end{array}$ & & \\
\hline & & $6-10$ & $28(47.5)$ & 31 (52.5) & & & & $6-10$ & $\begin{array}{c}24 \\
(40.7)\end{array}$ & $\begin{array}{c}35 \\
(59.3)\end{array}$ & & \\
\hline & & $1-5$ & 322 (65.8) & $196(34.2)$ & & & & $1-5$ & $\begin{array}{c}310 \\
(74.7)\end{array}$ & $\begin{array}{c}105 \\
(38.8)\end{array}$ & & \\
\hline
\end{tabular}

Table 5. Affective commitment among government health care provider in the Eastern Showa and Adama special zone, 2010.

\begin{tabular}{|c|c|c|c|c|c|c|c|c|}
\hline \multirow{2}{*}{ S. No } & \multirow{2}{*}{ Work Factors } & S. Disagre & Disagree & Indifferent & Agree & S. Agree & \multirow{2}{*}{ Mean } & \multirow{2}{*}{ S.D } \\
\hline & & No (\%) & No (\%) & No (\%) & No (\%) & No (\%) & & \\
\hline 1 & I desired to stay in this organization & $161(28.1 \%)$ & $113(19.7 \%)$ & $10(1.7 \%)$ & $72(12.6 \%)$ & 217 (37.9\%) & 3.1 & 1.72 \\
\hline 2 & $\begin{array}{l}\text { I'm willingness to exert high levels of } \\
\text { efforts on behalf of the organization; }\end{array}$ & $70(12.2 \%)$ & $118(29.6 \%)$ & $30(5.2 \%)$ & 175 (30.5\%) & $180(31.4 \%)$ & 3.5 & 1.42 \\
\hline 3 & $\begin{array}{l}\text { I accepting the values and } \\
\text { goals of an organizations }\end{array}$ & $105(18.3 \%)$ & $131(22.9 \%)$ & $23(4 \%)$ & $166(29 \%)$ & $148(25.8 \%)$ & 3.2 & 1.49 \\
\hline 4 & $\begin{array}{l}\text { I have a feeling of } \\
\text { emotionally attached }\end{array}$ & $103(18 \%)$ & $115(20.1 \%)$ & $31(5.4 \%)$ & $178(31.1 \%)$ & $146(25.5 \%)$ & 3.3 & 1.47 \\
\hline 5 & I have feeling of bright future & $110(19.2 \%)$ & 98 (17.1\%) & $24(4.2 \%)$ & $164(28.66 \%)$ & 177 (30.9\%) & 3.4 & 1.53 \\
\hline 6 & I have strong sense of belongingness & 77 (13.4\%) & $123(21.5 \%)$ & 17 (3\%) & 164 (28.6\%) & 192 (33.5\%) & 3.5 & 1.47 \\
\hline
\end{tabular}

tween 21 - 30, 18 (94.7\%) whose age less than 20 and 310 (74.7\%) of health workers who had service year of 1 - 5 were highly committed to their heath care organizations (Table 4).

\subsection{Factor Analysis}

To decide whether or not factor analysis was useful for the data, the KMO and Bartlett's test were computed and the following results were obtained. Extrinsic factors of work and affective commitment were $0.759,0.918$ and 0.925 respectively which was greater than 0.5 that $75.9 \%, 91.8 \%$ and $92.5 \%$ of the variance in the variables was due to the underline factors. In addition, Bartlett's test of sphericity also done and the chi-square value become 1572.25, $15 \mathrm{df}$ and p-value of 0.000 for intrinsic factors of work, 5874.49, $45 \mathrm{df}$ and with p-value of 0.000 for 
extrinsic factors of work and 4197, $15 \mathrm{df}$ and p-value of 0.000 . This indicated that, the variables were unrelated and therefore unsuitable for structure detection. Hence, factor analysis was useful for the data.

\subsection{Extrinsic Factors of Work}

The PCA in the Table 6 provides a two factor solution from the 10 items in the initial analysis (Eigen values = 6.8 and 1.2). As the Figure 2 shown for the scree test also suggested that, it was possible to extracts up to two factors. The scree test showed a clear break between Eigen values 1 and 2 and 3 . The break between 3 and 4 was not clear and it was then decided to analyse 1 and 2 factor that explains $79.6 \%$ of the variability in the original 10 variables. Following extraction, factors were rotated so as to make interpretations easier and the rotated component matrix was obtained to determine what each of the components represents. The first factor called as extrinsic factors_1 consisted of items (salary, fringe benefit, the incentive system, promotion and salary) which had a common interpretation of how much workers were dissatisfied/not dissatisfied with the financial incentive systems of an organizations, whereas items (post employment security and Relationship with co-workers) loading on the second factor called for extrinsic factors of work_2, also described workers dissatisfaction/no dissatisfaction level with non financial incentive system of an organization.

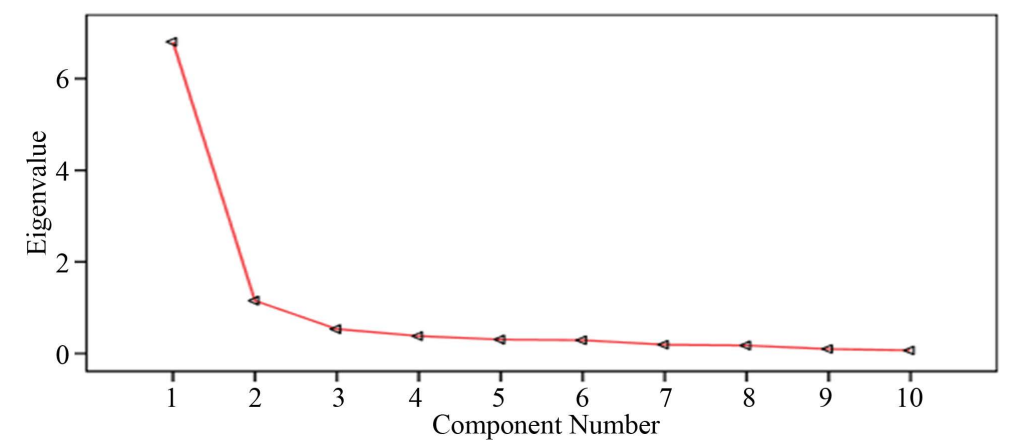

Figure 2. The scree test of extrinsic factors of work items Eastern Showa and Adama special zones, March $1^{\text {st }}$ to March $30^{\text {th }}, 2010$ Gc.

Table 6. Varimax rotated factor loadings for extrinsic factors of work items Eastern Showa and Adama special zones, March $1^{\text {st }}$ to $30^{\text {th }}, 2010$.

\begin{tabular}{cccc}
\hline S. No & Items & \multicolumn{2}{c}{ Factor loading } \\
\cline { 2 - 4 } Q301 & Salary & 1 & 2 \\
Q302 & Fringe benefits & $\mathbf{0 . 9 2 8}$ & 0.190 \\
Q303 & Promotion and salary increment & $\mathbf{0 . 9 0 5}$ & 0.244 \\
Q304 & Job security & $\mathbf{0 . 9 0 6}$ & 0.255 \\
Q305 & Health management welfare consideration & 0.581 & 0.561 \\
Q306 & The incentive system & 0.578 & 0.604 \\
Q307 & Opportunity for outside training & $\mathbf{0 . 8 3 3}$ & 0.373 \\
Q308 & Opportunity for in-house training & $\mathbf{0 . 7 3 1}$ & 0.491 \\
Q309 & Post employment security & 0.552 & 0.698 \\
Q310 & Relationship with co-workers & 0.339 & $\mathbf{0 . 8 2 2}$ \\
\hline
\end{tabular}

Extraction method: principal component analysis; rotation methods: varimax with Kaiser normalizations rotation converged in 3 item rations. 


\subsection{Affective Commitment}

As the results presented in the Table 7 shown, after PCA was made, one factor which is called as affective commitment_1 was extracted from the 6 items concerning affective commitment of health workers. In addition, the Figure 3 in annex for the scree test also suggested that, it was possible to extract up to one factor. This factor accounted for $84.54 \%$ of the variance in the score (Eigen values $=5.1$ ) and consisted all of the constructs of Meyer and Allen's affective commitment which had a common interpretation of how much workers were committed to their health care organizations.

\subsection{The Relationship between Health Professionals Characteristics, Extrinsic Factors of Work and Affective Commitment}

Findings from the correlations test among socio demographic variables and affective commitment_1 indicates, there was a strong positive correlation between type of health facility $(r=0.84, \mathrm{p}<0.01)$, location of health facility $(r=0.73, p<0.01)$, with affective commitment_1 whereas, professional category $(r=0.44, p<0.01)$, and sex $(r=0.40, p<0.01)$ have a moderate positive association with health workers affective commitment_1. On the other hand, age $(\mathrm{r}=-0.62$, and $\mathrm{p}<0.01)$, educational level $(\mathrm{r}=-0.62, \mathrm{p}<0.01)$, and income $(\mathrm{r}=-0.65, \mathrm{p}<$ 0.01 ) have a strong negative association with affective commitment_1 that represents all the constructs of Meyer and Allen's affective commitment. Similarly, service year $(\mathrm{r}=-0.52, \mathrm{p}<0.01)$, and marital status $(\mathrm{r}=-0.31, \mathrm{p}$ $<0.01$ ), have a moderate and weak correlation with workers affective commitment_1 respectively (Table 6). There was a strong positive correlation between extrinsic factors of work_1 with affective commitment_1 ( $\mathrm{r}=$ $0.61, \mathrm{p}<0.01)$ and a moderate positive association between extrinsic factors of work_2 and affective commitment_1 $(r=0.52, p<0.01)$. This indicates that, the lower the dissatisfaction of workers with extrinsic factors of work, the higher will be theirs affective commitment level (Table 8).

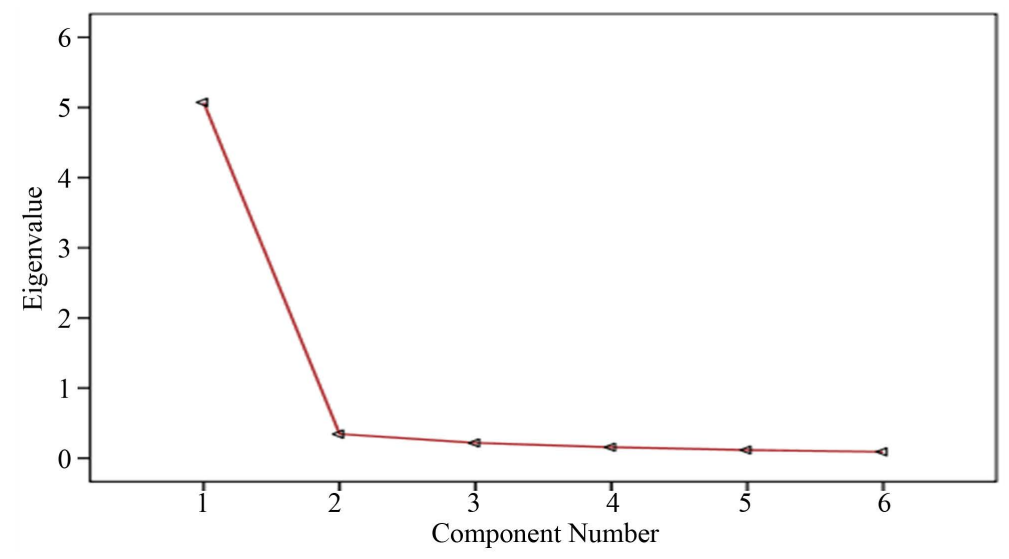

Figure 3. The scree test affective commitment items Eastern Showa and Adama special zones, March $1^{\text {st }}$ to March $30^{\text {th }}, 2010$.

Table 7. Factor loadings affective commitment items, Eastern Showa and Adama special zones, February $1^{\text {st }}$ to March $30^{\text {th }}, 2010$.

\begin{tabular}{lcc}
\hline S. No & Items & Factor \\
\hline Q501 & Intention to stay & $\mathbf{0 . 8 7 7}$ \\
Q502 & Willingness to exert high levels of efforts on behalf of the organization; & $\mathbf{0 . 8 8 4}$ \\
Q503 & Accepting the values and goals of an organizations & $\mathbf{0 . 9 3 2}$ \\
Q504 & Feeling of emotionally attached & $\mathbf{0 . 9 5 5}$ \\
Q505 & Feeling of bright future & $\mathbf{0 . 9 3 8}$ \\
Q506 & Strong sense of belongingness & $\mathbf{0 . 9 2 9}$ \\
\hline
\end{tabular}

Extraction method: principal component analysis; a.1 components extracte. 
Table 8. Pearson's correlation between socio-demographic factors, all work factors and affective commitment using factor score for the study done on government health workers in Eastern Showa and Adama special zones, 2010.

\begin{tabular}{|c|c|c|c|c|c|c|c|c|c|c|c|c|c|}
\hline S. No & Variables & 1 & 2 & 3 & 4 & 5 & 6 & 7 & 8 & 9 & 10 & 11 & 12 \\
\hline 1 & Type of HF & 1 & & & & & & & & & & & \\
\hline 2 & Location of HF & $0.77^{* *}$ & 1 & & & & & & & & & & \\
\hline 3 & Profession & $0.58^{* *}$ & $0.39^{* *}$ & 1 & & & & & & & & & \\
\hline 4 & Age & $-0.67^{* *}$ & $-0.60^{* *}$ & $-0.39^{* *}$ & 1 & & & & & & & & \\
\hline 5 & Sex & $0.45^{* *}$ & $0.35^{* *}$ & $0.22^{* *}$ & $-0.24^{* *}$ & 1 & & & & & & & \\
\hline 6 & Marital status & $-0.33^{* *}$ & $-0.30^{* *}$ & $-0.19^{* *}$ & $0.50^{* *}$ & 0.01 & 1 & & & & & & \\
\hline 7 & Educational level & $-0.76^{* *}$ & $-0.57^{* *}$ & $-0.66^{* *}$ & $0.48^{* *}$ & $-0.47^{* *}$ & $0.16^{* *}$ & 1 & & & & & \\
\hline 8 & Service year & $-0.55^{* *}$ & $-0.49^{* *}$ & $-0.33^{* *}$ & $0.82^{* *}$ & $-0.10^{*}$ & $40^{* *}$ & $0.39^{* *}$ & 1 & & & & \\
\hline 9 & Income & $0.73^{* *}$ & $0.62^{* *}$ & $0.60^{* *}$ & $0.60^{* *}$ & $0.47^{* *}$ & $0.30^{* *}$ & $0.76^{* *}$ & $0.46^{* *}$ & 1 & & & \\
\hline 10 & $\begin{array}{l}\text { Extrinsic factors } \\
\text { of work_1 }\end{array}$ & $0.66^{* *}$ & $0.57^{* *}$ & $0.39^{* *}$ & $0.40^{* *}$ & $0.32^{* *}$ & $0.24^{* *}$ & $0.56^{* *}$ & $0.41^{* *}$ & $0.51^{* *}$ & 1 & & \\
\hline 11 & $\begin{array}{l}\text { Extrinsic factors } \\
\text { of work_2 }\end{array}$ & $0.44^{* *}$ & $0.34^{* *}$ & $0.29^{* *}$ & $-0.40^{* *}$ & $0.28^{* *}$ & $-0.13^{* *}$ & $-0.37^{* *}$ & $-0.30^{* *}$ & $-0.40^{* *}$ & --- & 1 & 0.0 \\
\hline 12 & $\begin{array}{c}\text { Affective } \\
\text { commitment_1 }\end{array}$ & $0.84^{* *}$ & $0.73^{* *}$ & $0.44^{* *}$ & $-0.62^{* *}$ & $0.40^{* *}$ & $-0.31^{* *}$ & $-0.62^{* *}$ & $-0.52^{* *}$ & $-0.65^{* *}$ & $0.62^{* *}$ & $0.52^{* *}$ & 1 \\
\hline
\end{tabular}

${ }^{* *}$ Correlation is significant at 0.01 levels; ${ }^{*}$ Correlation is significant at 0.05 levels.

\subsection{Predictors of Health Workers Affective Commitment}

A stepwise multiple linear regression showed that, there exist statistically significant relation between commitment_1 with different independent variables $(\mathrm{F}=58.164, \mathrm{p}<0.0001)$ and the overall model fit (adjusted $\mathrm{R}^{2}=$ 81.1), and the following variables were identified as predictors of workers affective commitment. Being working in hospital decrease their affective commitment $(B=-1.165,95 \% \mathrm{CI}-1.27,-1.052, \mathrm{p}<0.0001)$ as compared to those working in health post. Similarly, those health workers who were general practitioners $(B=0.305,95 \% \mathrm{CI}$ 0.136, 0.474, p < 0.0001), health extension ( $\mathrm{B}=0.437$, 95\% CI 0.308, 0.566, $\mathrm{p}<0.0001$ ) and other type of health professionals $(\mathrm{B}=0.697,95 \% \mathrm{CI} 0.259,1.134, \mathrm{p}=0.002)$ were committed as compared to all type of nurses. Additionally, those health workers who earn 885 - $1636 \mathrm{birr} / \mathrm{month}$ were more committed by $(\mathrm{B}=0.155$, 95\% CI 0.054, 0.257, $\mathrm{p}=0.003$ ) as compared with those below $667 \mathrm{birr} /$ month (Table 9). Finally, the model explains that, as there are a decrease in dissatisfaction level of health workers with extrinsic factors of work_1 that representing (salary, the incentive system, opportunity for outside training, promotion and salary increment) and extrinsic factors of work_2 (post employment security and relationship with co-workers), leads to an increase health workers commitment level by $(\mathrm{B}=0.202,95 \%$ CI $0.152,0.253, \mathrm{p}<0.0001)$, and $(\mathrm{B}=0.231,95 \%$ CI $0.169,0.292, \mathrm{p}<0.0001$ ) respectively.

\section{Discussions}

The study attempted to shed light on health workers' affective commitment which is an important issue for health care organizations today. Meyer and Allen define affective commitment as employees' perceptions of their emotional attachment to their organization and its goals [9]. Similarly, the result revealed that $85.2 \%$ of health workers are committed to their health care organizations $(3.32+1.4), 62 \%$ are satisfied with overall content and context of work (mean score $=3.51$ and $\mathrm{SD}=0.93$ ). This finding is consistent with a cross-sectional study done among health workers in Iran hospitals [11], where the mean score of affective commitment is (mean score $=3.86$ and $\mathrm{SD}=1.12$ ). Again this finding was also supported with an exploratory study done in Georgia (mean score $=3.26$ ) and Jordan (mean score $=3.48$ ) hospitals [12].

Cross tabulation was made in between health workers' socio demographic characteristics and their affective commitment level to depict the presence and absences of association. The result pointed out that there was a significant difference between health workers affective commitment to their health care organizations and loca- 
Table 9. Multiple regression results with affective commitment as the outcome variable and socio demographic factors and work factors as predictors, for the study done on government health workers in Eastern Showa and Adama special zones. 2010.

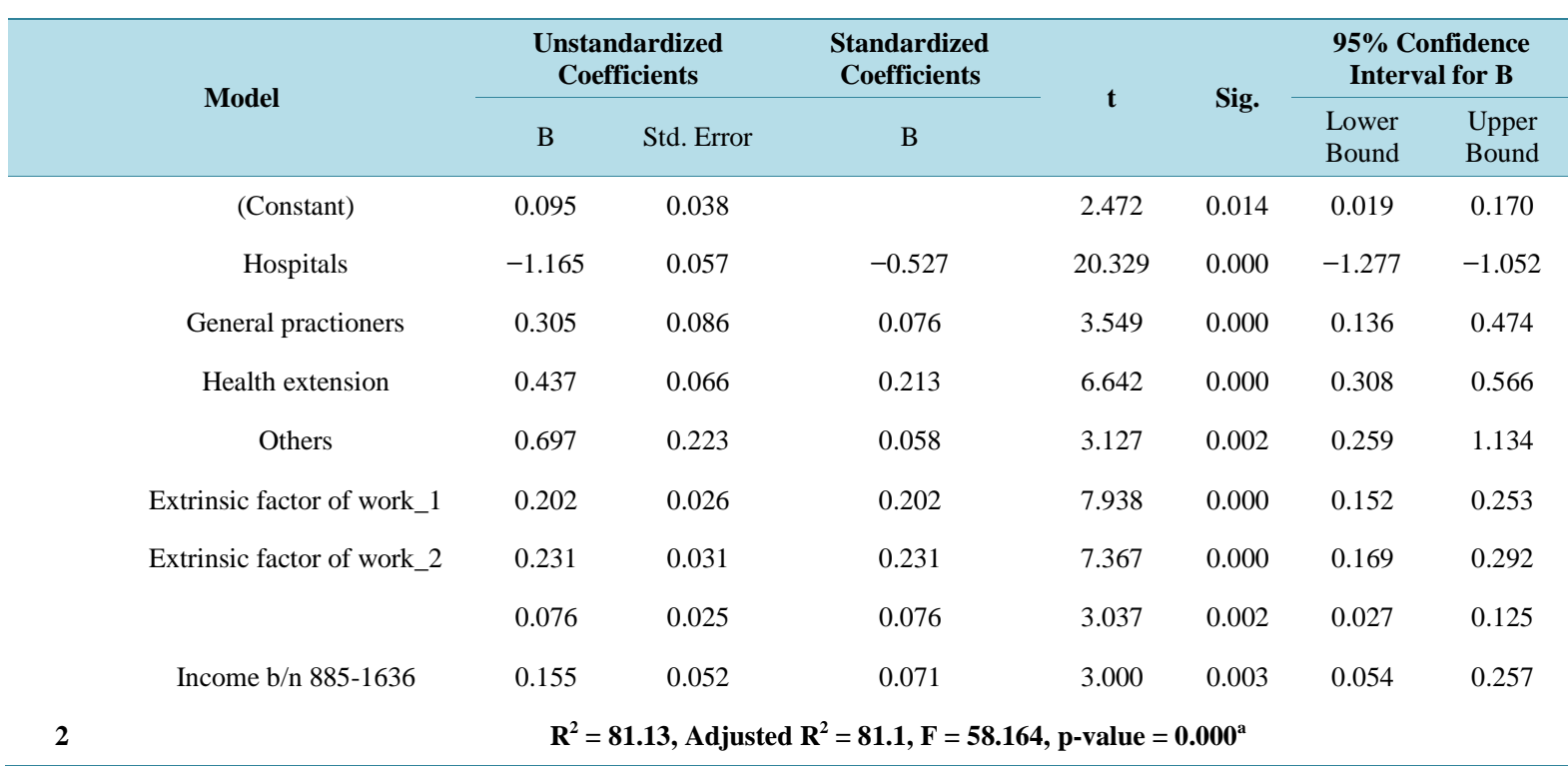

Predictors: (constant), hospitals, professions general practioners health extension, others type of professions, extrinsic factor of work factor_1, extrinsic factor of work factor_2, income b/n 885-1636. Dependent variables: affective commitment_1.

tion of health facility, age, monthly income, service year, educational level, marital status, sex and professions (p, 0.000). This finding goes in line with a study done in Iran [11] in which a significant difference was obtained between employees' organizational commitment and their marital status, age and years of work experiences, and salaries received (p, 0.03).

In addition, the model from a stepwise multiple linear regressions shows that the socio demographic and extrinsic factors of work, which explains $81.13 \%$ variance in health workers affective commitment. When this result was compared with similar study done in Iran [11], the simultaneous regression model indicates that organizational, social, job, and individual factors explained $44.7 \%$ of the variance in employees' organizational commitment. The difference on the two models may be due to the fact that the existence of difference on the socio demographic characteristic of respondents in both countries might have contributed for the model to be inflated. Moreover, adding of a few predictor variables from the Hertzberg's theory used in this study and the discrepancy on ways of data analysis may be the possible explanations.

According to Hertzberg theory, the variables for intrinsic factors are the primary causes of satisfaction, but the hygiene factors cannot. Rather, the hygiene factors if taken care of can only play a preventative role [13]. As the finding shows, workers of the two zones were less dissatisfied with extrinsic factors of work of which relationship with co-workers had the dominant mean value $(4+1.23)$ whereas, salary $(2.7+1.56)$, the incentive system $(2.5+1.67)$ and fringe benefit $(2.8+1.43)$ were scored less. Also, this finding were in line with, a cross sectional study done on health workers in Egypt, which shows the total mean score percent of job satisfaction was (56.8 $\pm 17.5)$ and relationship with colleagues $(81.3 \pm 19.6)$ represented the domain with highest percentage of satisfaction, while the domain of salaries/incentives represented the lowest satisfaction (16.2 \pm 14.7$)$ [14]. This finding again supported with an exploratory study done in Georgia [12] with the mean score of 3.23 for extrinsic factors of work as well 3.0 for overall job satisfaction level. Similarly, the study done in Jordan [12] also indicated that the mean score 3.04 for extrinsic factors of work and 2.37 for overall job satisfaction level. In line with the above, findings from the second wave of a Cohort Study of Young Ethiopian Doctors and Nurses [15] shows that, about $80 \%$ of the health workers are unsatisfied (20\%) or completely unsatisfied (about $60 \%$ ) with their salary. This finding revealed that salary could the major factor to affect workers commitment levels.

As it has been consistently reported by studies, there exists a positive association between job satisfaction and organizational commitment [15] [16]. Comparable with this, this study also confirmed the existence of a positive association in between health workers affective commitment and satisfaction with extrinsic factors of work. 
However, the present study had a number of strengths, like use of theories that served as a standard to discuss the finding, large area coverage and use of strong analysis methods. It had also some limitations due to the fact that the study was conducted after the application of the new strategies called BPR (Business Processing Reengineering) and during the time of election, that may induce social desirability bias. Moreover, this study did not consider other health workers who work in NGOs of the two zones that could be the major problem of external validity.

\section{Conclusion}

Health workers were less dissatisfied with overall extrinsic factors of work but highly dissatisfied with their monthly salary, fringe benefit, the incentive system, and promotion and salary increments. The higher workers dissatisfaction with extrinsic factors of work_1 which represents monthly salary, the incentive system, opportunity for outside training, promotion and salary increment and extrinsic factors of work_2 that represents post employment security and relationship with co-workers, the lower will be their affective commitments. Moreover, working in hospitals does have a negative effect on commitments as compared to health post workers. Being general practitioners, health extension and other professionals (community health agent) do have a positive effect on commitment level professionals as compared to all type of nurses, and earning a monthly income between 885 - 1636 birr positively increases the commitment level as compared to those who earn less than 667 birr/month. Therefore, policy makers in the ministry of health should revise their policy to bring some improvement on the extrinsic factors of work, such as, salary, fringe benefits, and the incentives system, of health care organizations by assessing the conditions of those factors in each health care organization. Plus, interested researchers should use the current finding and further explore the underline reasons for why working in hospitals decreases workers commitment as compared with those working in the PHCU.

\section{Competing Interests}

All the authors declared that, they have no any committing interest.

\section{Author's Contribution}

GT generate the topic, write the proposal, organize in data collection, did the analysis and prepare the manuscript. SH took part in data analysis and in manuscript writing. HA and TA participated in manuscript writing.

\section{Acknowledgements}

We would like to take this opportunity to thank Jimma University for sponsoring this study. Our special appreciation also goes to Mr Tewodrse Mekasha (MPH/E), who is M\&E advisor of works in JHU Tseha Project Hawassa, Ethiopia for his endless contributions.

\section{References}

[1] Christian, U. (2000) Working Condition and Employees Commitment in Indigenous Private Manufacturing Firms in Nigeria. The Journal of Modern Africa Studies, 38, 295-324. http://dx.doi.org/10.1017/S0022278X00003360

[2] World Health Organization (2006) Working Together for Health: The World Health Report. WHO, Geneva.

[3] Awases, M., Gbary, A., Nyoni, J. and Chatora, R. (2003) Migration of Health Professionals in Six Countries: A Synthesis Report. WHO-AFRO DHS, Brazzaville.

[4] Serra, D., Serneels, P. and Lindelow, M. (2008) Discovering the Real World: How Health Workers’ Early Work Experience Affects Their Career Preferences. Health Systems for Outcomes Publication.

[5] Kate, W. and Masako, T. (2002) Reframing Organizational Commitment within a Contemporary Careers Framework. Cornell University, Ithaca.

[6] Herzberg, F., Mausner, B. and Snyderman, B.B. (1959) The Motivation to Work. John Wiley \& Sons, New York.

[7] O’Reilly, C.A. and Chatman, J. (1986) Organizational Commitment and Psychological Attachment: The Effects of Compliance, Identification, and Attachment on Prosocial Behaviour. Journal of Applied Psychology, 71, 492-499. http://dx.doi.org/10.1037/0021-9010.71.3.492

[8] Tansik, D. (1980) Management: A Life-Cycle Approach. Irvin Dorsey, Homewood. 
[9] Meyer, J.P. and Allen, N.J. (1997) Commitment in the Workplace: Theory, Research, and Application. Sage, Newbury Park, 67.

[10] Nunnally, J.C. (1978) Psychometric Theory. 2nd Edition, McGraw Hill, New York.

[11] Mosadeghrad, A.M., et al. (2008) A Study of the Relationship between Job Satisfaction, Organizational Commitment and Turnover Intention among Hospital Employees. Health Services Management Research, 21, 211-227. http://dx.doi.org/10.1258/hsmr.2007.007015

[12] Francoa, L.M., et al. (2004) Determinants and Consequences of Health Worker Motivation in Hospitals in Jordan and Georgia. Social Science \& Medicine, 58, 343-355. http://dx.doi.org/10.1016/S0277-9536(03)00203-X

[13] Efere, P. (2005) Motivation and Job Satisfaction. Trans-Atlantic College, London.

[14] Abdel-Rahman, A.G., Fatma, M., Halim, A.W.E.A. and Allam, M.F. (2008) Low Job Satisfaction among Physicians in Egypt. TSK Koruyucu Hekimlik Bülteni, 7.

[15] Knoop, R. (1995) Relationships among Job Involvement, Job Satisfaction, and Organizational Commitment for Nurses. Journal of Psychology, 129, 643-649. http://dx.doi.org/10.1080/00223980.1995.9914935

[16] Ingersoll, G., Olsan, T., Drew-Cates, J., et al. (2002) Nurses’ Job Satisfaction, Organizational Commitment, and Career Intent. Journal of Nursing Administration, 32, 250-263. http://dx.doi.org/10.1097/00005110-200205000-00005 